\title{
INHIBITORY AND TREATMENT EFFECTS OF INTRAMUSCULARY DDS AND PROMIN USED UPON MURINE LEPROSY
}

\author{
Yasuro TAKAYAMA \\ Department of Bacteriology, Faculty of Medicine, \\ Hiroshima University (Director: Prof. K. Urabe)
}

25 of female white rats were divided in 5 groups. Group I was used as DDS inhibitory group, Group II DDS treatment, Group III Promin inhibitory, Group IV Promin treatment and Group $\mathrm{V}$ the control. In inhibitory experiments, from the next day of inoculation DDS of $0.1 \mathrm{mg}$. was injected 6 days in a week to the 7 th week and $0.2 \mathrm{mg}$. to the 13 th week and $0.4 \mathrm{mg}$. to the $22 \mathrm{th}$ week. By administration of Promin, since the next day $45 \mathrm{mg}$. was injected through the tail vein twice a week to the 22 th week. With the treatment experiment, 4 weees after inoculation elapsed and then animals received the DDS and Promin in the same manner as the inhibitory experiments.

As the results, intramusculary DDS seems to be inferior to Promin both in the administration method and doses used in this experiments.

\section{筋注用 DDS 及び Promin の鼠瀬に対する}

\section{発症阻止並びに治療効果について}

\author{
高山保 郎 \\ （昭和 32 年 1 月 4 日受稿） \\ 広島大学医学部細菌学教室（主任 占部 薰教授） \\ 一本論文の要旨は日本軉学会西部地方会第 4 回総会（昭和 30 年10月，長崎）に於て発表した——
}

\section{緒言}

われわれ(1)2) は既に Streptomycin, PAS, Tibione, Promin, Cepharanthin, INAH の鼠瀨に対する治療効果に ついて検討するところがあつたが，今回は筋注用 $\mathrm{DD}^{\mathrm{S}}$ 及び Promin の鼠癩に対する発症阻止並びに治療効果 について追究したので以下報告する。

\section{I 実 験 方 法}

a ）供試獣：体重 95〜150 g の雌性白鼠 25匹。

b ）供試菌：鼠瀨菌熊本株儿感染させた白鼠の瀨性肉 芽（接種後 284 日目）よりの生塩水による 1,000 倍乳郕 の 1,000 r.p.m. 5 分間遠沈後の上清菌液 $0.5 \mathrm{cc}$ 宛を白 鼠の右側側腹部皮下に接種した。

c ）供埥薬品及び白鼠群別：筋注用 $0.1 \% \mathrm{D} \mathrm{D} \mathrm{S} \mathrm{及び}$ $30 \%$ Protomin（何れも吉富製薬）を供試し，第 1 群を
D D S 発症阻止群，第 2 群を同治療群,第 3 群をPromin 発症阻止群, 第 4 群を同治療群及び第 5 群を対照群とし て各 5 匹宛供試した。

b ）投薬方法：まず発症阻止群に於てはD D \& は接種 翌日より 7 週迄は 1 回 $0.1 \mathrm{mg}, 7$ 週より 13 週迄は 0.2 $\mathrm{mg}, 13$ 週より 22 週迄は $0.4 \mathrm{mg}$ をいずれす週 6 回宛筋 注した。又 Promin は接種翌日より 22 週迄 1 回 $45 \mathrm{mg}$ 宛を週 2 回尾静脈内に注射した。

次に治療群に於ては鼠瀨菌を接種後 4 週間放置して以 後は発症阻止群と同様に各々注射した。

このようにして各群投薬の結果の総投薬量は第 1 群 D D S $33 \mathrm{mg}$, 第 2 群同 $23.4 \mathrm{mg}$, 第 3 群 Promin $1.98 \mathrm{~g}$ 第 4 群同 $1.62 \mathrm{~g}$ となつた。

e ）観察：週 1 回体重の測定並びに体表変化の検査を 行い, 菌接種後 22 週目に剖検した。剖険時に於ては瀨 性肉芽の大きさ立びに重量, 湘巴腺（左右㯟べき, 鼠 
蹊, 腋窩, 頸部及び腸骨, 腸間膜, 後腹壁）の腫大度及 び変化並びに諸内臓 (肺, 肝, 脾, 腎, 副腎, 卵巣, 骨 盤脂脂組織) の変化及びこれらよりの塗抹標本による鼠

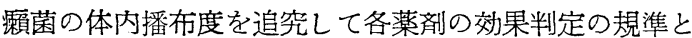
した。

\section{II 実 験 成 績}

a ）一般状態並びに体表所見：第 1 群の No. 1 は菌接
種 70 日後に獘死したが，その他の試獣は概して活気が あり，体重も各群漸増の傾向を示した。

体表変化は表 1 に示したよらに第 4 群 No. 16 に於て 菌接種局所に一致して帽針頭大の瘦孔形成が認められた ほかには何れの試獣にも異常は認められなかつた。

d ）肉眼的剖検所見：瀨性肉芽，淋巴腺及び内臟の肉 眼的剖検所見もをとめて表 1 に示したが。すず雄性肉芽 に於ては第 1 群 No. 1 を除き全試獣に 菌種局所に相当

表 1 肉眼的剖検所見の総括

\begin{tabular}{|c|c|c|c|c|c|c|c|c|c|c|c|c|}
\hline \multirow{2}{*}{$\begin{array}{l}\text { 群 } \\
\text { 別 }\end{array}$} & \multirow{2}{*}{ No. } & \multirow{2}{*}{$\begin{array}{l}\text { 生 } \\
\text { 存 } \\
\text { 数 }\end{array}$} & \multirow{2}{*}{$\begin{array}{l}\text { 生 } \\
\text { 死 }\end{array}$} & 体 & 重（g） & \multirow{2}{*}{$\begin{array}{l}\text { 体 } \\
\text { 表 } \\
\text { 㚆 } \\
\text { 化 }\end{array}$} & 黂 & 肉 & 芽 & 淋 & 巴腺 & \multirow{2}{*}{ 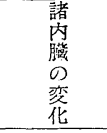 } \\
\hline & & & & 開始時 & 剖検時 & & $\begin{array}{c}\text { 面 }(\mathbf{c m})^{\text {積 }} \\
\end{array}$ & $\mathrm{C}^{\text {重 }}(\mathrm{g})^{\text {量 }}$ & $\mid$\begin{tabular}{|c|} 
重量平均 \\
\end{tabular} & 喱大度 & 変＼cjkstart化 & \\
\hline \multirow{5}{*}{$\begin{array}{l}\text { 怘 } \\
\text { 發 } \\
\text { 症 } \\
\text { 肯 } \\
\text { 群 }\end{array}$} & 1 & 70 & 死 & 100 & 85 & $(-)$ & 不明 & 不 明 & \multirow{5}{*}{$\begin{array}{c}0.85 \\
(4 匹)\end{array}$} & 1.7 & $(-)$ & $(-)$ \\
\hline & 2 & 154 & 殺 & 100 & 135 & $(-)$ & $2.4 \times 1.8$ & 0.6 & & 1.6 & $(-)$ & $(-)$ \\
\hline & 3 & 154 & 殺 & 130 & 145 & $(-)$ & $1.7 \times 2.0$ & 1.2 & & 2.0 & $(-)$ & $(-)$ \\
\hline & 4 & 154 & 殺 & 120 & 145 & $(-)$ & $2.0 \times 2.5$ & 1.0 & & 2.2 & $(-)$ & $(-)$ \\
\hline & 5 & 154 & 殺 & 110 & 145 & $(-)$ & $2.0 \times 2.1$ & 0.6 & & 2.3 & $(-)$ & $(-)$ \\
\hline \multirow{5}{*}{$\begin{array}{l}\text { 导 } \\
\text { 治 } \\
\text { 療 } \\
\text { 群 }\end{array}$} & 6 & 154 & 殺 & 110 & 155 & $(-)$ & $2.0 \times 2.1$ & 0.9 & \multirow{5}{*}{0.84} & 2.1 & $(-)$ & $(-)$ \\
\hline & 7 & 154 & 殺 & 140 & 150 & $(-)$ & $2.0 \times 2.3$ & 0.8 & & 2.0 & $(-)$ & $(-)$ \\
\hline & 8 & 154 & 殺 & 115 & 135 & $(-)$ & $2.8 \times 1.5$ & 0.8 & & 1.7 & $(-)$ & $(-)$ \\
\hline & 9 & 154 & 殺 & 120 & 150 & $(-)$ & $1.9 \times 3.7$ & 0.8 & & 1.5 & $(-)$ & $(-)$ \\
\hline & 10 & 154 & 殺 & 100 & 135 & $(-)$ & $2.4 \times 1.5$ & 0.9 & & 1.9 & $(-)$ & $(-)$ \\
\hline \multirow{5}{*}{ 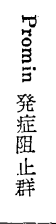 } & 11 & 154 & 殺 & 140 & 170 & $(-)$ & $1.8 \times 1.2$ & 0.8 & \multirow{5}{*}{0.60} & 2.0 & $(-)$ & $(-)$ \\
\hline & 12 & 154 & 殺 & 150 & 135 & $(-)$ & $2.8 \times 0.9$ & 0.3 & & 2.1 & $(-)$ & $(-)$ \\
\hline & 13 & 154 & 殺 & 110 & 165 & $(-)$ & $2.2 \times 3.0$ & 0.6 & & 2.1 & $(-)$ & $(-)$ \\
\hline & 14 & 154 & 殺 & 120 & 150 & $(-)$ & $1.8 \times 0.7$ & 0.7 & & 2.2 & $(-)$ & $(-)$ \\
\hline & 15 & 154 & 殺 & 125 & 165 & $(-)$ & $1.5 \times 1.3$ & 0.6 & & 2.2 & $(-)$ & $(-)$ \\
\hline \multirow{5}{*}{$\begin{array}{l}\text { 范 } \\
\text { E. } \\
\text { 治 } \\
\text { 療 } \\
\text { 群 }\end{array}$} & 16 & 154 & 殺 & 95 & 145 & $\mathrm{~F}$ & $2.5 \times 1.5$ & 3.2 & \multirow{5}{*}{0.87} & 2.5 & $\begin{array}{l}\text { 右测穉へキ } \\
\text { 腺 }\end{array}$ & $(-)$ \\
\hline & 17 & 154 & 殺 & 125 & 150 & $(-)$ & $1.8 \times 1.3$ & 0.3 & & 1.6 & $(-)$ & $(-)$ \\
\hline & 18 & 154 & 殺 & 135 & 160 & $(-)$ & $1.2 \times 0.8$ & 0.1 & & 1.7 & $(-)$ & $(-)$ \\
\hline & 19 & 154 & 殺 & 115 & 165 & $(-)$ & $2.8 \times 1.4$ & 0.7 & & 2.0 & $(-)$ & $(-)$ \\
\hline & 20 & 154 & 殺 & 100 & 145 & $(-)$ & $0.3 \times 1.0$ & $0.1<$ & & 2.1 & $(-)$ & $(-)$ \\
\hline \multirow[t]{2}{*}{ 対 } & 21 & 154 & 殺 & 115 & 155 & $(-)$ & $2.4 \times 1.3$ & 0.9 & \multirow{5}{*}{1.04} & 2.0 & $(-)$ & $(-)$ \\
\hline & 22 & 154 & 殺 & 130 & 195 & $(-)$ & $4.0 \times 2.6$ & 2.5 & & 1.8 & $(-)$ & $(-)$ \\
\hline 照 & 23 & 154 & 殺 & 140 & 135 & $(-)$ & $3.0 \times 2.1$ & 0.9 & & 1.7 & $(-)$ & $(-)$ \\
\hline \multirow{2}{*}{ 群 } & 24 & 154 & 殺 & 140 & 165 & $(-)$ & $2.4 \times 1.6$ & 0.6 & & 2.0 & $(-)$ & $\begin{array}{l}\text { 左督白色結 } \\
\text { 質 } 19\end{array}$ \\
\hline & 25 & 154 & 殺 & 130 & 170 & $(-)$ & $2.0 \times 1.0$ & 0.3 & & 2.0 & $(-)$ & $(-)$ \\
\hline
\end{tabular}

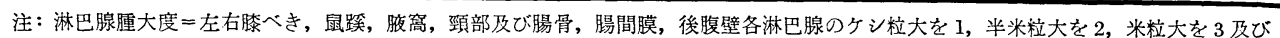

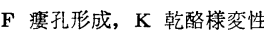

して菲膜状のうすい肉芽組織から腫㿔状のbのに至る種 々の程度のものがみられその中特第 4 群 No. 16 及び 第 5 群 No. 22 に於ては $3.2 \mathrm{~g}$ 及び $2.5 \mathrm{~g}$ の大肉芽組 織の形成が証明された。
な招，癩性肉芽の平均重量では第 3 群 (Promin 発症 阻止群) が最も小さく, 第 1 群 (D D S 発症阻止群), 第 2 群（D D S 治療群），第 4 群（Promin 治療群）は 略同程度であり第 5 群（対照群）は最も大であつた。 
次に淋巴腺に於ては第 4 群 No. 16 の左側膝べき淋巴 腺に乾酪様変化が認められた他には各試獣間に腫大度に 於ける著差は求められなかつた。

内臟に於ては第 5 群 No. 24 の左腎に小豆大の白色結
節が 1 コ認められたほかにはその他の試獣にはいうほど の見所はなかつた。

c ）顕微鏡的所見：鼠瀨菌の体内播布度は一括して困 1 にヒストグラムとして示した。

図 1 鼠瀨菌の体内播布相

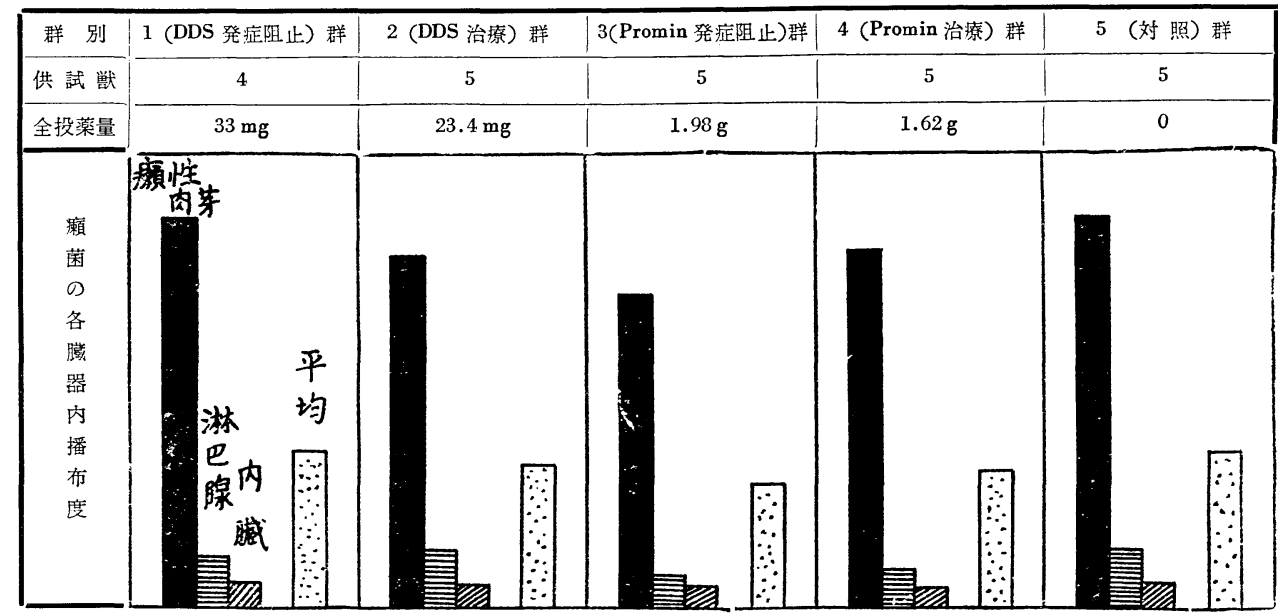

即ち，とれで判るように鼠瀨菌の体内播布の程度は 3 群 $<4$ 群 $<2$ 群 $<1$ 群う対照群の順となつた。な打，検 出菌の菌長, 顆粒数及び被染性については特に各群相互 間に差は認められなかつた。

\section{総括並びに考按}

D D S の鼠㿉に対する治効に関しては, Hobby $5^{3)}$, 西村 5)5) は否定して抢り, Chang 6)7)8), 吉永 ${ }^{9)}$ はこれ を認めている。又 Promin の鼠瀨に対する効果につい ては, Hobby $5^{3)}$, 中村 ${ }^{10)}$, 谷奥 ${ }^{11)}$, 大国 ${ }^{12)}$ 及び高山ら 1) により程度の差とそあれいずれるとれを認めているが 他方西村ら ${ }^{13)}$ は否定的な報告をしている。

ところで今回の私の実験では, D D S投与量は人体径 口投与量を参考にして最初 $0.1 \mathrm{mg}$ 宛, 7 週後 $0.2 \mathrm{mg}$ 宛, 更に 13 週後 $0.4 \mathrm{mg}$ 宛に増量しつつ週 6 回の割合で 22 週後迄投与し, Promin は前報1)の毎回 $30 \mathrm{mg}$ よりも 増加して毎回宛投与としたのであるが，その結果による と癩性肉芽の増生度は Promin 発症阻止群 $<$ D D S 発 症阻止群 同治療群 $\fallingdotseq$ Promin 治療群<対照群の順とな り, 又菌の体内播布度に於ては Promin 発症阻止群<同 治療群 < D D S 治療群<同発症阻止群文対照群の順とな つた。

従来, Promin, Diasone などの誘導体の治攋作用機転 としては主として血中の游離D D Sによるものであると されて括り, 従つててれら諉導体によつて与えられらる
僅かなD D SによるよりはD D S 自体を直接投与するこ とが効果的であららととは当然考えられるととろであ る。但しこの場合とてもその投与量乃至投与方法のいか んによつてはその効果に多かれ少かれ差異の生ずるとと はこれ亦当然想像されるととろであり，中村ら ${ }^{14)}$ は Promin についてその皮下投与よりは静脈内投与の方がよ り有効でめつたと報告し, 又 Chang ${ }^{6)}$ は $0.01 \%$ D D S の経口投与よりは $0.1 \%$ D D S 投与の方がより効果的 でめつたと報告している。

ところで今回の私の如上の実験の限りに於ては筋注用 D D S は Promin に比して鼠瀨の発症阻止, 治療のいず れに於ても多少とも劣つているような所見がえられた が，これは西村ら ${ }^{4)}$ がD D S はその大量を経口投与して

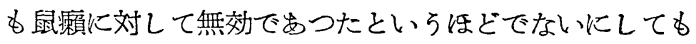
Promin 及びD D S は鼠瀨白鼠に対して同等の効果を認 めたといら吉永 ${ }^{9)}$ の報告とはやや趣を異にするものであ る。

\section{結論}

筇注用 D D S の鼠癩の発症阻止効果並びに治療効果は 今回のそれの投与法並びに投与量の限りに於ては Promin に劣るよらである。

（擱筆するに当り御愁篤な御指導並びに御校閲をいただ いた恩師占部教授並びに薬品を分与して戴いた吉富製薬 に対して感謝する。) 


\section{主 要 文 献}

1) 高山・安元 : レプラ, 22 ( 1 ), 18, 昭 28

2) 高山: レプラ, 23(2), 71, 昭29

3 ) Hobby, G. L. and Hanks J. H.: Am. Rev. Tuberc., 16, 173, 1954

4) 西村・増田他 2 名：レプラ，24( 5 )，283, 昭30

5 ) 西村・岩佐：レプラ，25(1)，1，昭31

6) Chang, Y. T. : Internat. J. Leprosy, 21( 1 ), 57, 1953
7) Chang, Y. T.: Internat. J. Leprosy, 22( 3 ), 331 1954

8 ) Chang, Y. T.: Intpernat. J. Lerosy, 23( 2), 167 1955

9 ) 吉永: レプラ, 25 ( 1 ), 31, 昭31

10）中村: レプラ, 19 ( 5$), 21$, 昭 25

11）谷奥: レプラ, $20(6), 173$, 昭 26

12）大国: 医学研究，21（8）,72, 昭26

13）西村・河野・本多：レプラ，19（6），22，昭25

14) 中村・新宮：レプラ，20（4)，109, 昭26 